\title{
SERUM LIPID PROFILE AND ARTERIAL STIFFNESS IN NON-DIPPERS
}

\author{
*A.B. Bawa-Allah', M.M. Mashao², T.F. Nyundu'2, E.M. Phukubje', \\ B.G. Nkosi' ${ }^{2}$ M.V. Ngema ${ }^{2}$, B.W. Mlambo ${ }^{2}$, M.J. Maseko² \\ 1 - COLLEGE OF MEDICINE, UNIVERSITY OF LAGOS, LAGOS, NIGERIA \\ 2 - UNIVERSITY OF THE WITWATERSRAND, JOHANNESBURG, SOUTH AFRICA
}

Background. A non-dipping blood pressure profile (NDP) is associated with increased arterial stiffness and other cardiovascular target organ damage. Serum lipid profiles have been shown to be important determinants of arterial stiffness.

Objective. The aim of the research was to assess serum lipid profiles and arterial stiffness in non-dippers.

Methods. This cross-sectional study was conducted involving 796 (288 males and 508 females) participants of black African origin. A twenty-four-hour ambulatory BP monitoring was done using a Spacelabs 90207 (Spacelabs Inc., Redmond, Washington, USA) monitor. Carotid-Femoral pulse wave velocity measurements were performed using a high fidelity SPC-301 micromanometer (Millar instruments Inc., Houston, TX).

Results. Of the 288 males, 140 were classified as non-dippers. Of the 508 females, 273 were classified as non-dippers. In the general population, males had higher triglycerides when compared with females $1.46 \pm 0.96$ vs 1.13 $\pm 1.02, p<0.0001$. Additionally, dipper males had higher serum TRGL when compared with dipper females $1.32 \pm 0.98$ vs $1.06 \pm 0.58, p=0.0012$. Non-dipper males also had higher serum TRGL when compared with nondipper females $1.61 \pm 2.05$ vs $1.19 \pm 1.14, p=0.0078$. Serum HDLC was lower in the non-dipper male group when compared to the non-dipper female group ( $p=0.008)$. In both male and female groups, non-dippers had higher CFPWV when compared with dippers; $7.53 \pm 3.60$ vs $5.74 \pm 2.47, p<0.0001$ and $6.64 \pm 2.52$ vs $5.98 \pm 2.23, p=0.0021$ respectively. However, non-dipper males had significantly higher CFPWV when compared with non-dipper females (7.53 \pm 3.60 vs $6.64 \pm 2.52, p=0.0031)$.

Conclusions. Therapies targeting a reduction of serum triglycerides levels might be beneficial in improving arterial compliance with or without the presence of non-dipping.

KEYWORDS: Non-dipping; arterial stiffness; lipids.

\section{Introduction}

A non-dipping blood pressure profile (NDP) is defined as failure of the night-time blood pressure (BP) values to drop by a minimum of $10 \%$ of the daytime values [1]. A non-dipping blood pressure profile (NDP) is associated with increased arterial stiffness and other cardiovascular target organ damage and is also a stronger predictive index of cardiovascular morbidity and mortality [2]. Arterial stiffness, which is one of the complications of non-dipping, is an established marker of arteriosclerosis and subclinical atherosclerosis and is an independent predictor of future adverse cardiovascular events [3]. Various techniques are available to assess arterial stiffness but some of these are inconvenient. Carotid-femoral pulse wave velocity (CF-PWV) is a simpler, practical and more reproducible way of evaluating arterial stiffness. It is considered the 'gold standard' for the measurement of arterial stiff-

*Corresponding author: Abdulraheem B. Bawa-Allah, Department of Physiology, College of Medicine, University of Lagos, Ishaga Road, Idi-Araba, 01234, Lagos.

E-mail: abbawaallah@gmail.com. ness [4]. It has been proved that increase in arterial stiffness is an independent predictor of all causes of cardiovascular morbidity and mortality [5]. Cardiovascular risk factors such as age, diabetes and hypertension have been established to be positively associated with arterial stiffness [6]. However, the contribution of serum lipids to the development of arterial stiffness is not clear. Studies on the relationship between serum lipids and arterial stiffness have been conflicting $[7,8]$. Additionally, there is no data investigating the possible role of serum lipid profile in non-dipping related increase in arterial stiffness. Thus, the study was focused on describing the serum lipid profile in nondipping related increase in arterial stiffness measured by CF-PWV.

\section{Methods \\ Study Population}

This study was approved by the Human Research Ethics Committee HREC (medical) of the University of the Witwatersrand Johannesburg South Africa (HREC approval number 
M170213). This study was carried out according to the Helsinki declaration on ethical principles for medical research involving human subjects. The participants gave informed, written consents before the commencement of the study. Standard questionnaire was given to the participants to record data on medical history, smoking habits, alcohol intake, gender and age. The participants were randomly recruited from the SOWETO area of Johannesburg South Africa and were of black African origin. Of the 1,219 participants enrolled in this study only $796 \mathrm{had}$ complete 24-hour ambulatory BP monitoring reports and their data was included in the statistical analysis. The minimum age of the participants was 18 years old.

\section{Anthropometric measurements}

Height, weight, waist and hip circumference were measured while the participants were in the standing position with no shoes on. Height was expressed in meters $(\mathrm{m})$ while waist and hip circumferences were expressed in centimetres $(\mathrm{cm})$. Body mass index (BMI) was expressed as $\mathrm{kg} / \mathrm{m}^{2}$.

Ambulatory blood pressure measurements

A twenty-four-hour ambulatory BP monitoring was carried out during the participants' typical working day or a day involving their usual activities using a Spacelabs 90207 (Spacelabs Inc., Redmond, Washington, USA) monitor. The monitor was programmed to measure $\mathrm{BP}$ at 15-minute intervals from 06:00 to 22:00 and then 30-minute intervals from 22:01 to 05:59. Participants were instructed to note the time they go to bed and the time they wake up in the morning in an activity diary which was used to determine 'awake' and 'asleep' periods. Upon completion, data was transferred from the ambulatory BP monitors to a computer for analysis. A recording was considered as successful if at least $90 \%$ of valid recordings were obtained. Participants were classified as dippers if their nocturnal drop in 24-hour systolic BP was $>10 \%$ and as non-dippers if they had a nocturnal drop in 24-hour systolic BP of $<10 \%$.

Carotid-Femoral Pulse Wave Velocity (CFPWV) measurement

Carotid-Femoral PWV measurements were conducted to determine the level of arterial stiffness. After resting for about 15 minutes in the supine position, CF-PWV was measured using a high fidelity SPC-301 micromanometer (Millar instruments Inc., Houston, TX) interfaced with a computer running SphygmoCor software version 9.0 (AtCor Medical Pty. Ltd., West Ryde, New South Wales, Australia). Pulse pressure waveforms were recorded from the right common carotid artery and the right femoral artery. Pulse wave velocity was calculated automatically by the software.

\section{Blood sample collection}

Venous blood samples to determine serum lipid profiles were taken for the participants by an experienced qualified nurse who is part of the research group. The participants were asked to relax, and blood sample was collected in the sitting position. For plasma analyses, blood samples were collected into $9 \mathrm{ml}$ EDTA Vacuette ${ }^{\circledR}$ (Greiner Bio One International $\mathrm{GmbH}$ ) blood collection tubes. Blood samples were collected into $5 \mathrm{ml}$ Vacuette ${ }^{\circledR}$ Serum Gel tubes, gently inverted and allowed to clot for 30 minutes. The sample was then centrifuged at $2200 \mathrm{~g}$ for 15 minutes and the serum was carefully removed with a fine-bore pipette and then stored in properly labelled sterile vials and stored at $8^{\circ} \mathrm{C}$ before pick-up by the laboratory. Samples were then picked up by the staff of CLS (Clinical Laboratory Services) at the National Health Laboratory Service (NHLS), South Africa, for analysis. All samples were taken to the laboratory within 7 days of blood collection.

\section{Statistical analysis}

All data were analysed using STATA (StataCorp LLC Texas USA) data analysis and statistical software version 13.0. Data were expressed as mean \pm standard deviation (SD) for continuous variables. Categorical variables were expressed as absolute or relative frequencies or as percentages. A test for normality of continuous variables was assessed using Shapiro-Wilk's statistic or $\chi^{2}$ test for categorical variables. Comparisons between dipper and non-dipper groups as well as gender groups were done using independent Student's t-test or one-way analysis of variance (ANOVA) (with post hoc Bonferroni tests). Simple regression was used to determine the relationship between carotid femoral pulse wave velocity and age in both genders. A P-value of $<0.05$ was considered as statistically significant.

\section{Results}

\section{Demographic and clinical characteristics}

The study population consisted of 796 participants and was classified according to gender and BP dipping status. There were a total of 288 males and 508 females. Of the 288 males, 148 were classified as dippers while 140 were classified as non-dippers. Of the 508 females, 235 were classified as dippers while 273 were classified as being non-dippers. In 
both gender groups, non-dippers were older than dippers; $49.79 \pm 18.84$ vs $39.06 \pm 17.88$, $\mathrm{p}<0.0001$ in the male group and $46.61 \pm 17.45$ vs 41.25 $\pm 17.33, p=0.0003$ in the female group. Body mass index (BMI) was higher in females when compared to males in the general population $31.13 \pm 7.89$ vs $24.96 \pm 5.14, p<0.0001$. Additionally, females had higher BMI than males irrespective of dipping status. Waist circumference was higher in the female nondipper group when compared with the male dipper group (88.23 \pm 15.22 vs $83.42 \pm 13.31$, $p=0.02$ ) and also higher in the female nondipper group when compared with the female dipper group $(94.13 \pm 17.38$ vs $89.50 \pm 15.35$, $\mathrm{p}=0.0008)$. Females had higher waist circumference when compared with males irrespective of dipping status and gender group. There were more hypertensive participants in the nondipper groups when compared with the dipper groups irrespective of gender. There were also more diabetic participants in the male nondipper group when compared to the male dipper group. Males in the general population had higher triglycerides (TRGL) when compared with females in the general population $1.46 \pm 0.96$ vs $1.13 \pm 1.02, p<0.0001$. Additionally, dipper males had higher serum TRGL when compared with dipper females $1.32 \pm 0.98$ vs $1.06 \pm 0.58$ $p=0.0012$. Non-dipper males also had higher serum TRGL when compared with non-dipper females $1.61 \pm 2.05$ vs $1.19 \pm 1.14, p=0.0078$. Within the same gender group, serum triglycerides were not different between dipper and nondippers. Serum HDLc was lower in males when compared with females in the general popu- lation $(p<0.0001)$. Serum HDLc was also lower in the non-dipper male group when compared to the non-dipper female group $(p=0.008)$. Females had higher serum LDLc when compared to males in the general population $2.72 \pm 0.89 \mathrm{vs}$ $2.48 \pm 0.62, p<0.0001$. Serum LDLc levels did not differ between dippers and non-dippers within gender groups; however, LDLc levels were higher in the female non-dipper group when compared with the male non-dipper group $(p<0.05)$. There were no differences in other clinical and demographic characteristics. These results are presented in Table 1.

Carotid femoral pulse wave velocity (CFPWV) by gender and dipping status

In both male and female groups, nondippers had higher CFPWV when compared with dippers; $7.53 \pm 3.60(n=130)$ vs $5.74 \pm 2.47$ $(n=134), p<0.0001$ and $6.64 \pm 2.52(n=232)$ vs $5.98 \pm 2.23(n=203), p=0.0021$ respectively. Nondipper males however had significantly higher CFPWV when compared with non-dipper females $(7.53 \pm 3.60$ vs $6.64 \pm 2.52, p=0.0031)$. These results are presented in Figure 1.

Relationship between age and carotid femoral pulse wave velocity (CFPWV)

Carotid Femoral Pulse Wave Velocity increased with age amongst males and females irrespective of dipping status. However, the age-related increase in CFPWV was steeper in males when compared to females $(p<0.0001)$ irrespective of dipping status. The age-related increase in CFPWV was steeper in both nondipper males and females when compared to dipper males and dipper females $(p<0.0001)$. These results are presented in Figure 2.
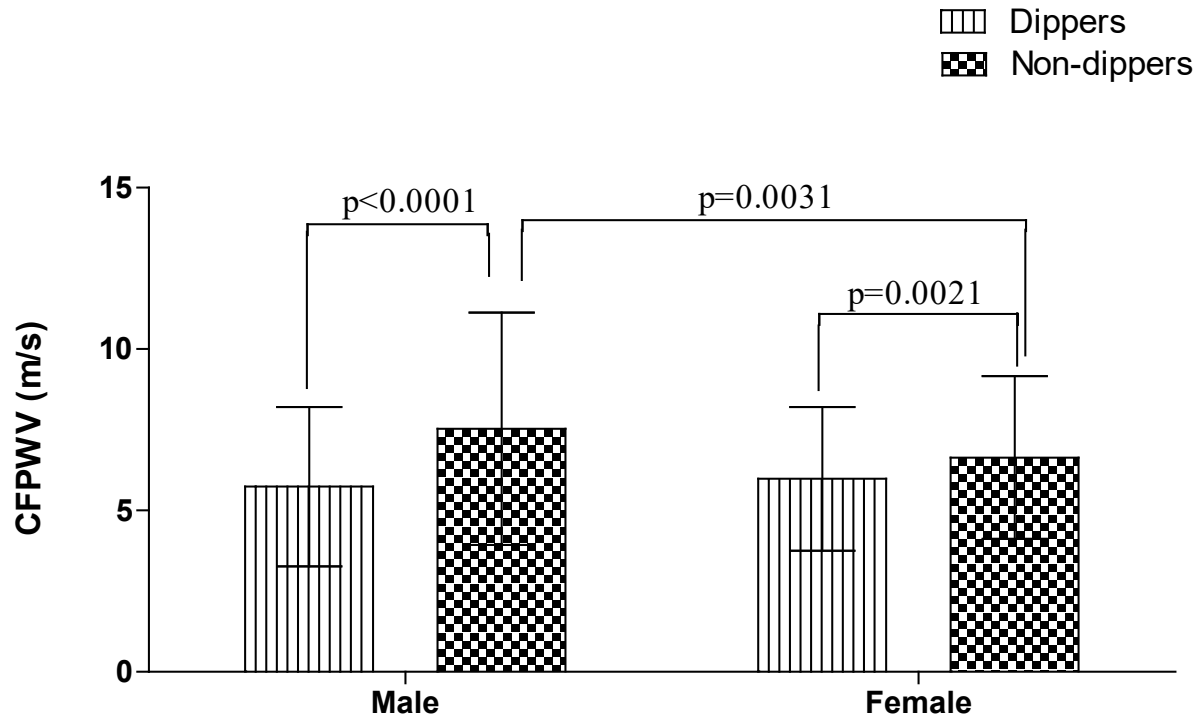

Fig. 1. Carotid femoral pulse wave velocity (CFPWV) of the participants according to blood pressure dipping status and gender. Results are presented as mean \pm SD. 


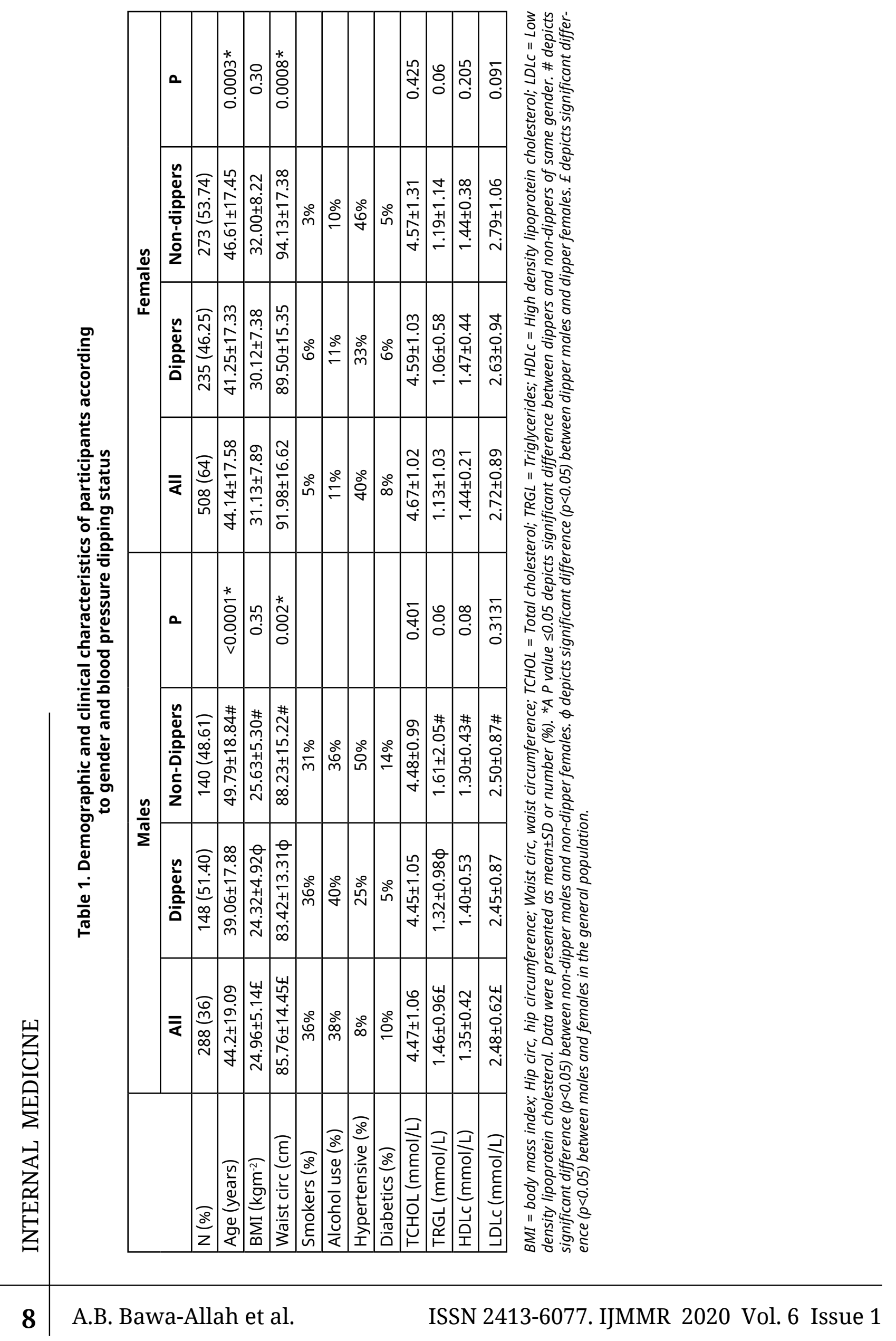



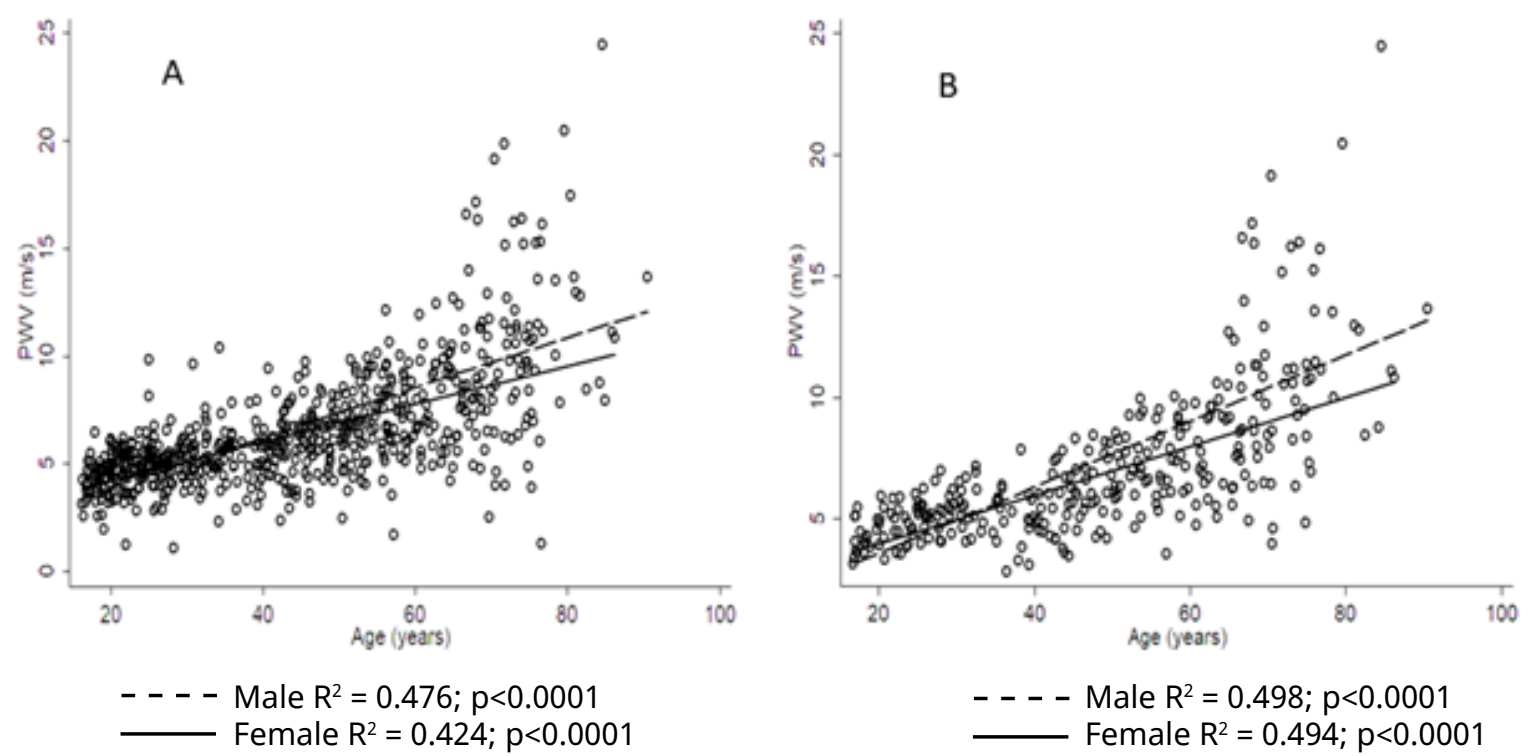

Fig. 2. Age related increase in pulse wave velocity. Panel A represents dippers population while panel $B$ represents non-dippers. PWV = Pulse Wave Velocity.

\section{Discussion}

In this cross-sectional study of black South Africans, it was demonstrated that non-dippers have higher arterial stiffness as measured by CFPWV when compared with dippers. We also show that male non-dippers have greater arterial stiffness and greater age-related increase in arterial stiffness when compared with female non-dippers. Males had significantly higher serum triglycerides when compared with females irrespective of blood pressure dipping status. To our knowledge, this is the first time that serum lipid profiles are considered in nondipping related arterial stiffness.

The males in our cohort had greater levels of triglycerides irrespective of dipping status irrespective of dipping status. We believe that serum triglycerides might explain the higher arterial stiffness observed in males. This is consistent with the findings of Wang and colleagues where they showed in a communitybased study involving 1, 447 participants, that lower levels of triglycerides were significantly associated with decreases in CFPVW even after adjusting for confounding variables [9]. Zhao and colleagues also showed similar results [10]. They established that serum triglycerides had a positive relationship with brachial ankle pulse wave velocity (baPWV) in 1133 participants aged from 50 to 90 .

The present study shows a significantly lower serum HDLc in non-dipper males when compared with non-dipper females. This might also explain the gender differences in arterial stiffness between non-dipper males and fe- males. The role of HDLc in arterial stiffness has been studied and it has been suggested that low levels of HDLc is a risk factor for cardiovascular and cerebrovascular diseases [11]. Similarly, different studies have shown an inverse relationship between HDLc and pulse wave velocity, suggesting that higher levels of HDLc might be associated with an improved arterial distensibility [12]. Wang and colleagues in a cross-sectional study showed that in 15 , 302 participants, HDLc had an inverse relationship with CFPWV [13]. Because of the large population of this study and similarity in technique used in the assessment of arterial stiffness, we are confident about the validity of our results. Of interest is also the study by Shen and colleagues where it is shown that high serum levels of HDLc are associated with a lower risk of arterial stiffness specifically in women older than 50 years of age but not in age matched men and not in individuals younger than 50 years old [14]. The exact mechanism behind the relationship between HDLC and CFPWV is not quite clear but it has been postulated that high HDLc levels are inversely proportional to advanced glycation end products levels (AGEs) [15] which stimulate inflammatory pathways and stress signaling and can damage elastin molecules in the vascular wall leading to arterial stiffness [16]. It has also been shown that HDLC has beneficial effects on the vascular wall via its anti-apoptotic, anti-inflammatory and antithrombotic properties [17].

Additionally, we also show in this study that female non-dippers had higher LDLc concen- 
trations when compared with non-dipper males. Although high serum levels of LDLc have been attributed to higher degrees of arterial stiffness [18], this might not explain the observed gender differences in arterial stiffness in this study. This suggests that LDLc might be less important at determining arterial stiffness when compared with HDLc and triglycerides in this population. This assumption may be supported by trials that have shown significant residual cardiovascular risk even when LDLC levels have reached treatment target levels. This residual cardiovascular risk has been attributed to high triglycerides levels despite normal LDLc levels [19]. It has also been shown that levels of HDLc have better prognostic capabilities when compared to levels of LDLc [20].

The significantly higher pulse wave velocity in non-dipper males could have also been accounted for by higher prevalence of diabetes in this group. Alecu and colleagues showed in 207 participants a strong correlation between diabetes and arterial stiffness and a stronger relationship between pulse wave velocity and age in diabetic individuals when compared with non-diabetic individuals [21], although the nondipping component was not considered. A relatively larger study with 1,415 participants showed higher prevalence of arterial stiffness amongst diabetic participants. They also showed a higher risk of increased arterial stiffness amongst diabetic individuals in a 5-year follow-up study [22].

The present study shows an increase in CFPWV with age irrespective of gender, with males having a steeper increase in age related arterial stiffness when compared to females irrespective of dipper status. These observations are consistent with those of Alghathrif and colleagues where they showed in a population of 777 individuals with 354 men and 423 women, that men had a steeper longitudinal increase in CFPWV with advancing age when compared with women, which makes the males to have higher CPFPWV values after their fifth decade [23]. Our results are also in line with another study by Wen and colleagues [24] in which arterial stiffness was assessed by cardio-ankle vascular index (CAVI) in 18, 336 subjects and it was observed that aging led to a higher arterial stiffness in men when compared with women. Magalhães and colleagues also showed that males above 50 years old had a greater pulse wave velocity when compared to age matched females [25]. However, in contrast to our findings there are observations by Nethononda and colleagues where it was evidenced that females showed a steeper increase in aortic stiffness with age when compared with males [26]. This study consisted of 777 individuals with 408 females and 369 males. The pulse wave velocity was assessed using cardiovascular magnetic resonance. Similarly, a study by Tomiyama and colleagues reported that age induced arterial stiffness as measured by brachial ankle pulse wave velocity was higher in females when compared to males. This study involved 7,881 subjects with 4,488 males and 3,393 females [27]. The differences in observations between the latter mentioned studies are not quite clear, but despite their large sample sizes, they employed different methods to assess arterial stiffness. All the studies mentioned above have been conducted in general populations and the nocturnal BP dipping statuses of the participants were not taken into consideration. The reports that studied the non-dipping BP pattern alongside arterial stiffness did not consider age and gender differences [28]. Our results suggest that non-dipping related arterial stiffness is more severe in males when compared to females causing them to have a higher non-dipping related arterial stiffness and a steeper increase in age related arterial stiffness when compared with females. Aging is associated with increased sympathetic activation [29] and may lead to inflammation. Inflammation has been shown to induce arterial stiffness [30].

Our study population was modest in size and consisted entirely of black Africans living in Africa, this might limit the generalizability of our findings. Also, our study was crosssectional, therefore, cause-effect relationships cannot be established.

\section{Conclusions}

The nocturnal non-dipping blood pressure profile is associated with higher arterial stiffness and a steeper age-related increase in arterial stiffness irrespective of gender. Nondipper males have higher level of arterial stiffness and age-related increase in arterial stiffness when compared with non-dipper females. Therapies targeting a reduction of serum triglycerides levels might be beneficial in improving arterial compliance with or without the presence of non-dipping.

\section{Conflict of interest}

The authors report no conflict of interests in this study 


\section{Funding}

This work was supported The University of the Witwatersrand Enablement Grant, and The Faculty of Health Sciences Research Grant, Grant number: 001.251.8521101.5121105. 000000. 0000000000.4550.

\section{Acknowledgements}

All participants formed an integral part of this study, without which the study would have been realizable. We appreciate their voluntary contributions.

\section{Author's contribution}

Abdulraheem B. Bawa-Allah - conceptualization, formal analysis, investigation, methodology, project administration, software, vali- dation, visualization, writing-original draft, writing-review and editing; Mercy M. Mashao investigation, methodology, project administration; Thamsanqa F. Nyundu - investigation, methodology, project administration; Edgar $M$. Phukubje - investigation, methodology, project administration; Brian G. Nkosi - investigation, methodology, project administration; Mandisa V. Ngema - investigation, methodology, project administration; Bongubuhle W. Mlambo - investigation, methodology, project administration; MuziJ. Maseko - conceptualization, investigation, methodology, project administration, validation, visualization, writing- review and editing, supervision.

\title{
ЛІПІДНИЙ СПЕКТР КРОВІ ТА АРТЕРІАЛЬНА ЖОРСТКІСТЬ У ПАЦІЕНТІВ 3 NON-DIPРЕR-ДОБОВИМ ПРОФІЛЕМ АРТЕРІАЛЬНОГО ТИСКУ
}

\author{
*A.B. Bawa-Allah¹, M.M. Mashao², T.F. Nyundu², E.M. Phukubje², \\ B.G. Nkosi' ${ }^{2}$ M.V. Ngema ${ }^{2}$, B.W. Mlambo ${ }^{2}$, M.J. Maseko ${ }^{2}$ \\ 1 - COLLEGE OF MEDICINE, UNIVERSITY OF LAGOS, LAGOS, NIGERIA \\ 2 - UNIVERSITY OF THE WITWATERSRAND, JOHANNESBURG, SOUTH AFRICA
}

Вступ. Добовий профіль артеріального тиску (AT) поn-dipper, який супроводжується недостатнім зниженням АТ вночі, асоціюється з підвищеною жорсткістю артерій та ураженням органів-мішеней. Ліпідний профіль - одна з важливих детермінант артеріальної жорсткості.

Мета роботи. Мета дослідження - оцінити взаємозв'язки між ліпідним спектром крові та артеріальною жорсткістю у пацієнтів з добовим профілем AT non-dipper.

Методи. Було проведене поперечне (одномоментне) дослідження 796 (288 чоловіків та 508 жінок) осіб-африканців. 24-годинний добовий моніторинг AT проводили з використанням обладнання Spacelabs 90207 (Spacelabs Inc., Redmond, Washington, USA). Швидкість поширення пульсової хвилі по артеріях еластичного типу (ШППХ) визначали за допомогою мікроманометра SPC-301 (Millar instruments Inc., Houston, $T X)$.

Результати. Серед 288 чоловіків у 140 добовий профіль АТ був типу поn-dipper. Серед 508 жінок цей

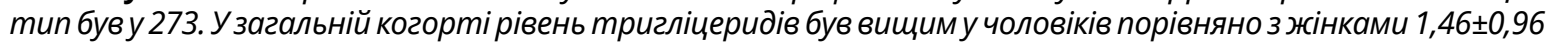

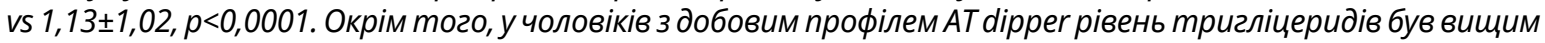
відносно жінок-dippers $1,32 \pm 0,98$ vs $1,06 \pm 0,58(p=0,0012)$ відповідно. Non-dippers-чоловіки мали вищий рівень

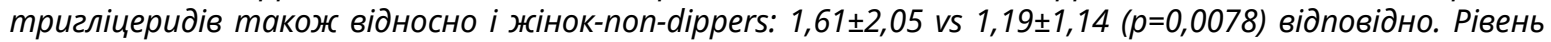
ліпопротеїдів високої щільності був достовірно нижчим у чоловіків-non-dippers порівняно з жінками з групи non-dippers ( $p=0.008)$. У обох статей і чоловіків $і$ жінок поn-dippers ШППХ була вищою у порівнянні з

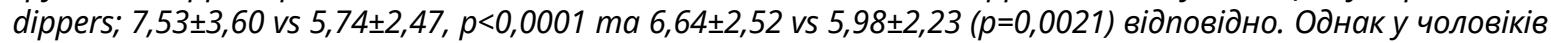

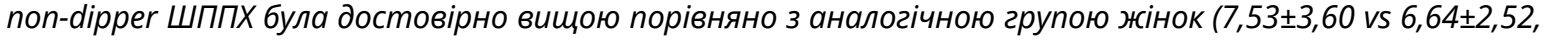
$p=0,0031$ ).

Висновки. Враховуючи отримані нами дані, фармакотерапія спрямована на зниження рівня тригліцеридів у сироватці крові може впливати на перебіг артеріальної гіпертензії та ії наслідки незалежно від типу добового профілю артеріального тиску.

КЛЮЧОВІ СЛОВА: Non-dipping профіль артеріального тиску; артеріальна жорсткість; ліпідний профіль крові.

Information about authors

Abdulraheem B. Bawa-Allah - Department of Physiology, College of Medicine, University of Lagos, Lagos Nigeria.

ORCID https://orcid.org/0000-0003-0829-3007, e-mail: abbawaallah@gmail.com 
Mercy M. Mashao - South African Hypertension and Diet Study, School of Physiology, Faculty of Health Sciences, University of the Witwatersrand, Johannesburg, South Africa.

ORCID https://orcid.org/0000-0002-1119-2736, e-mail: mercy.mashao@yahoo.com

Thamsanqa F. Nyundu - South African Hypertension and Diet Study, School of Physiology, Faculty of Health Sciences, University of the Witwatersrand, Johannesburg, South Africa.

ORCID https://orcid.org/0000-0003-1609-0859, e-mail: thaminyundu@gmail.com

Edgar M. Phukubje - South African Hypertension and Diet Study, School of Physiology, Faculty of Health Sciences, University of the Witwatersrand, Johannesburg, South Africa.

ORCID https://orcid.org/0000-0003-0486-217X, e-mail: ephukubje@gmail.com

Brian G. Nkosi - South African Hypertension and Diet Study, School of Physiology, Faculty of Health Sciences, University of the Witwatersrand, Johannesburg, South Africa.

ORCID https://orcid.org/0000-0003-1741-3656, e-mail: brian.g.nkosi@gmail.com

Mandisa V. Ngema - South African Hypertension and Diet Study, School of Physiology, Faculty of Health Sciences, University of the Witwatersrand, Johannesburg, South Africa.

ORCID https://orcid.org/0000-0003-0601-5433, e-mail: mandisangema29@icloud.com

Bongubuhle W. Mlambo - South African Hypertension and Diet Study, School of Physiology, Faculty of Health Sciences, University of the Witwatersrand, Johannesburg, South Africa.

ORCID https://orcid.org/0000-0002-4517-5723, e-mail: bongubuhle@gmail.com

Muzi J. Maseko - South African Hypertension and Diet Study, School of Physiology, Faculty of Health Sciences, University of the Witwatersrand, Johannesburg, South Africa.

ORCID https://orcid.org/0000-0002-0055-114X, e-mail: muzi.maseko@wits.ac.za

\section{References}

1. Head GA, Mihailidou AS, Duggan KA, Beilin LJ, Berry N, Brown MA, Bune AJ, Cowley D, Chalmers JP, Howe PR, Hodgson J. Definition of ambulatory blood pressure targets for diagnosis and treatment of hypertension in relation to clinic blood pressure: prospective cohort study. Bmj. 2010 Apr 14;340:1104.

doi: $10.1136 /$ bmj.c1104

2. Hansen TW, Jeppesen J, Rasmussen S, Ibsen H, Torp-Pedersen C. Ambulatory blood pressure monitoring and risk of cardiovascular disease: a population based study. American journal of hypertension. 2006 Mar 1;19(3):243-50.

doi: 10.1016/j.amjhyper.2005.09.018

3. Blacher J, Guerin AP, Pannier B, Marchais SJ, Safar ME, London GM. Impact of aortic stiffness on survival in end-stage renal disease. Circulation. 1999 May 11;99(18):2434-9.

doi: 10.1161/01.cir.99.18.2434

4. Laurent S, Cockcroft J, Van Bortel L, Boutouyrie P, Giannattasio C, Hayoz D, Pannier B, VlachopouIos C, Wilkinson I, Struijker-Boudier H. Expert consensus document on arterial stiffness: methodological issues and clinical applications. European heart journal. 2006 Nov 1;27(21):2588-605.

doi: 10.1093/eurheartj/ehl254

5. Laurent S, Boutouyrie P, Asmar R, Gautier I, Laloux B, Guize L, Ducimetiere P, Benetos A. Aortic stiffness is an independent predictor of all-cause and cardiovascular mortality in hypertensive patients. Hypertension. 2001 May;37(5):1236-41.

doi: 10.1161/01.hyp.37.5.1236

6. Reference Values for Arterial Stiffness' Collaboration. Determinants of pulse wave velocity in healthy people and in the presence of cardiovascular risk factors: 'establishing normal and reference values'. European heart journal. 2010 Oct 1;31(19): 2338-50.

doi: 10.1093/eurheartj/ehq165

7. Aggoun Y, Bonnet D, Sidi D, Girardet JP, Brucker E, Polak M, Safar ME, Levy BI. Arterial mechanical changes in children with familial hypercholesterolemia. Arteriosclerosis, thrombosis, and vascular biology. 2000 Sep;20(9):2070-5.

doi: 10.1161/01.atv.20.9.2070

8. Hansen TW, Staessen JA, Torp-Pedersen C, Rasmussen S, Thijs L, Ibsen $\mathrm{H}$ and Jeppesen J. Prognostic value of aortic pulse wave velocity as index of arterial stiffness in the general population. Circulation. 2006;113:664-70.

doi: 10.1161/circulationaha.105.579342

9. Wang X, Ye P, Cao R, Yang X, Xiao W, Zhang Y,

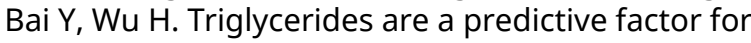
arterial stiffness: a community-based 4.8-year prospective study. Lipids in health and disease. $2016 \mathrm{Dec}$ 1;15(1):97-105.

doi: 10.1186/s12944-016-0266-8

10. Zhao W, Gong W, Wu N, Li Y, Ye K, Lu B, Zhang Z, Qu S, Li Y, Yang Y, Hu R. Association of lipid profiles and the ratios with arterial stiffness in middle-aged and elderly Chinese. Lipids in health and disease. 2014 Dec 1;13(1):37-42.

doi: 10.1186/1476-511x-13-37

11. Assmann G, Gotto Jr AM. HDL cholesterol and protective factors in atherosclerosis. Circulation. 2004 Jun 15;109(23_suppl_1):III-8.

doi: 10.1161/01.cir.0000131512.50667.46

12. Zhao WW, Yang YH, Lu B, Feng XC, He M, Yang ZH, Wen J, Zhang ZY, Yang Z, Li Q, Ye Z. Serum highdensity lipoprotein cholesterol and progression to arterial stiffness in middle-aged and elderly Chinese. 
Nutrition, Metabolism and Cardiovascular Diseases.

2013 Oct 1;23(10):973-9.

doi: 10.1016/j.numecd.2012.08.001

13. Wang $X$, Du $Y$, Fan $L, Y e ~ P$, Yuan $Y$, Lu $X$, Wang F, Zeng Q. Relationships between HDL-C, hsCRP, with central arterial stiffness in apparently healthy people undergoing a general health examination. PLoS One. 2013 Dec 3;8(12):e81778.

doi: 10.1371/journal.pone.0081778

14. Shen WC, Lu FH, Yang YC, Wu JS, Chang YF, Huang $\mathrm{YH}$, Chang $\mathrm{C}$. The relationship between highdensity lipoprotein cholesterol levels and arterial stiffness in a Taiwanese population. Nutrition, Metabolism and Cardiovascular Diseases. $2017 \mathrm{Dec}$ 1;27(12):1136-42.

doi: 10.1016/j.numecd.2017.10.003

15. Chang JB, Chu NF, Syu JT, Hsieh AT, Hung YR. Advanced glycation end products (AGEs) in relation to atherosclerotic lipid profiles in middle-aged and elderly diabetic patients. Lipids in health and disease. 2011 Dec 1;10(1):228-34.

doi: 10.1186/1476-511x-10-228

16. Zieman SJ, Melenovsky V, Kass DA. Mechanisms, pathophysiology, and therapy of arterial stiffness. Arteriosclerosis, thrombosis, and vascular biology. 2005 May 1;25(5):932-43.

doi: 10.1161/01.atv.0000160548.78317.29

17. Campbell S, Genest J. HDL-C: clinical equipoise and vascular endothelial function. Expert review of cardiovascular therapy. 2013 Mar $1 ; 11(3): 343-53$.

doi: $10.1586 /$ erc. 13.17

18. Bjornstad P, Nguyen N, Reinick C, Maahs DM, Bishop FK, Clements SA, Snell-Bergeon JK, Lieberman R, Pyle L, Daniels SR, Wadwa RP. Association of apolipoprotein B, LDL-C and vascular stiffness in adolescents with type 1 diabetes. Acta diabetologica. 2015 Jun 1;52(3):611-9.

doi: 10.1007/s00592-014-0693-9

19. Sampson UK, Fazio S, Linton MF. Residual cardiovascular risk despite optimal LDL cholesterol reduction with statins: the evidence, etiology, and therapeutic challenges. Current atherosclerosis reports. 2012 Feb 1;14(1):1-0.

doi: 10.1007/s11883-011-0219-7

20. Nilsson G, Öhrvik J, Lönnberg I, Hedberg P. Ten-year survival in 75-year-old men and women: predictive ability of total cholesterol, $\mathrm{HDL}-\mathrm{C}$, and LDL-C. Current gerontology and geriatrics research. 2009 Jan 1;2009;3:6-12.

doi: $10.1155 / 2009 / 158425$

21. Alecu C, Gueguen $R$, Aubry $C$, Salvi P, PerretGuillaume C, Ducrocq X, Vespignani H, Benetos A. Determinants of arterial stiffness in an apparently healthy population over 60 years. Journal of human hypertension. 2006 Oct;20(10):749-56.

doi: $10.1038 /$ sj.jhh. 1002072

22. de Oliveira Alvim R, Santos PC, Musso MM, de Sá Cunha R, Krieger JE, Mill JG, Pereira AC. Impact of diabetes mellitus on arterial stiffness in a representative sample of an urban Brazilian population.
Diabetology \& metabolic syndrome. 2013 Dec $1 ; 5(1): 45-52$.

doi: 10.1186/1758-5996-5-45

23. AlGhatrif M, Strait JB, Morrell CH, Canepa M, Wright J, Elango P, Scuteri A, Najjar SS, Ferrucci L, Lakatta EG. Longitudinal trajectories of arterial stiffness and the role of blood pressure: the Baltimore Longitudinal Study of Aging. Hypertension. 2013 Nov;62(5):934-41.

doi: 10.1161/hypertensionaha.113.01445

24. Wen W, Peng B, Tang X, Huang HX, Wen X, Hu $S$ and Luo R. Prevalence of high arterial stiffness and gender-specific differences in the relationships with classical cardiovascular risk factors. J Athero Thromb. 2015;22:706-17.

doi: $10.5551 /$ jat. 26690

25. Magalhães $P$, Capingana $D P$, Silva $A B$, Ferreira AV, de Sá Cunha R, Rodrigues SL, Mill JG. Age-and gender-specific reference values of pulse wave velocity for African adults: preliminary results. Age. 2013 Dec 1;35(6):2345-55.

doi: 10.1007/s11357-012-9504-9

26. Nethononda RM, Lewandowski AJ, Stewart R, Kylinterias I, Whitworth P, Francis J, Leeson P, Watkins $\mathrm{H}$, Neubauer S, Rider OJ. Gender specific patterns of age-related decline in aortic stiffness: a cardiovascular magnetic resonance study including normal ranges. Journal of Cardiovascular Magnetic Resonance. 2015 Dec 1;17(1):20-9.

doi: 10.1186/s12968-015-0126-0

27. Tomiyama $H$, Yamashina A, Arai T, Hirose $K$, Koji Y, Chikamori T, Hori S, Yamamoto Y, Doba N, Hinohara S. Influences of age and gender on results of noninvasive brachial-ankle pulse wave velocity measurement-a survey of 12517 subjects. Atherosclerosis. 2003 Feb 1;166(2):303-9.

doi: 10.1016/s0021-9150(02)00332-5

28. Jerrard-Dunne $P$, Mahmud A, Feely J. Circadian blood pressure variation: relationship between dipper status and measures of arterial stiffness. Journal of hypertension. 2007 Jun 1;25(6):1233-9.

doi: 10.1097/hjh.0b013e3280eec79f

29. Barnes JN, Hart EC, Curry TB, Nicholson WT, Eisenach JH, Wallin BG, Charkoudian N, Joyner MJ. Aging enhances autonomic support of blood pressure in women. Hypertension. 2014 Feb;63(2):303-8. doi: 10.1161/hypertensionaha.113.02393

30. Johnson CP, Baugh R, Wilson CA, Burns J. Age related changes in the tunica media of the vertebral artery: implications for the assessment of vessels injured by trauma. Journal of clinical pathology. 2001 Feb 1;54(2):139-45.

doi: 10.1136/jcp.54.2.139

Received 27 Mar 2020; revised 19 May 2020; accepted 05 June 2020.

This is open access article distributed under the Creative Commons Attribution License, which permits unrestricted use, distribution, and reproduction in any medium, provided the original work is properly cited. 